\title{
Comparative efficacy of essential oils of three aromatic plants as alternatives in the control of Phytophthora spp., agent of cocoa tree (Theobroma cacao L.) black pod disease in Côte d'Ivoire
}

\author{
Klotioloma COULIBALY ${ }^{1 *}$, F. J. M. Koffi KASSI ${ }^{2}$, Adama OUATTARA ${ }^{1,3}$, \\ GOGBE-Dibi B. F. ${ }^{1}$, P. Walet N'GUESSAN ${ }^{1}$, J.A. Kotaix ACKA ${ }^{1}$, M. Evelyne ASSI ${ }^{1}$, \\ N. N'Dri KOUAME ${ }^{1}$, Brigitte GUIRAUD ${ }^{1}$, M. Gnion TAHI ${ }^{1}$, Daouda KONE ${ }^{2}$, \\ Ibrahim KONATE ${ }^{3}$ and F. Kouamé N'GUESSAN ${ }^{1}$ \\ ${ }^{1}$ National Center of Agronomic Research, PO Box 808, Divo (Côte d'Ivoire). \\ ${ }^{2}$ Laboratory of Plant Physiology, Faculty of Biosciences, Félix Houphouët-Boigny University, 22 PO Box 582 \\ Abidjan 22 (Côte d'Ivoire). \\ ${ }^{3}$ Laboratory of Agrovalorization, Department of Biochemistry and Microbiology, Faculty of Agroforestry, \\ Jean Lorougnon Guédé University, PO Box 150 Daloa (Côte d'Ivoire). \\ *Corresponding author; E-mail: coolklotiolo@yahoo.fr
}

\begin{tabular}{lll}
\hline Received: 26-05-2021 & Accepted: 21-07-2021 & Published: 31-08-2021 \\
\hline
\end{tabular}

\begin{abstract}
This study aimed at comparing the efficacy of essential oils from three aromatic plants species (Cymbopogon citratus, Eucalyptus citriodora and Ocimum gratissimum) in vitro and in vivo against two Phytophthora strains (Phytophthora palmivora and P. megakarya) in a view to developing new biofongicides for the control of cocoa tree black pod disease. Essential oils were applied at four different concentrations (0.5; 1; 3 and $5 \mathrm{~mL} / \mathrm{L}$ ) in vitro and in vivo on leaf discs of three cocoa clones (NA32, PA150 and SCA6) which susceptibility is known. As results, all three essential oils significantly $(\mathrm{p}<0.05)$ reduced in vitro mycelial growth of both Phytophthora strains and also reduced the leaf susceptibility to these strains. Inhibition rates in vitro of Phytophthora strains mycelial growth ranged from 83.80 to $100 \%$ for the essential oils of Cymbopogon citratus and Ocimum gratissimum species and from 17.7 to $100 \%$ for which of Eucalyptus citriodora species. In the biotests, the leaf susceptibility index of clone NA32 (susceptible) was reduced from 3.14 to 0.40 . This correspond to reduction rates ranged from 64.87 to $86.70 \%$ of leaf susceptibility to both Phytophthora strains. Essential oils (HS and HO) from Cymbopogon citratus and Ocimum gratissimum species were most effective than which from Eucalyptus citriodora species. However, all three essential oils revealed antifungal properties. Therefore, they could be recommended as biofungicides for a sustainable control of cocoa tree black pod disease in Côte d'Ivoire. (C) 2021 International Formulae Group. All rights reserved.
\end{abstract}

Keywords: Efficacy; Essential oils; Phytophthora; Black pod disease; Biofungicides.

\section{INTRODUCTION}

In Côte d'Ivoire, cocoa is the main export crop (ICCO, 2000). With a production of 1,964,000 tons in 2017-2018, Côte d'Ivoire is the world's leading cocoa producer (ICCO, 2019). Cocoa farming occupies an area of over $2,000,000$ hectares $(6 \%$ of the national territory) and involves a farming population of 
over 800,000 producers (CCC, 2014; Friedel et al., 2016). Cocoa generates more than $30 \%$ of export earnings and contributes more than $15 \%$ to the Gross Domestic Product (GDP); (CCC, 2014; Friedel et al., 2016). Despite this remarkable performance, cocoa farming remains subject to numerous production constraints (Assiri et al., 2012; Ploetz, 2016). Among these constraints, black pod disease is currently one of the main sources of productivity losses in Ivorian cocoa farms (Coulibaly et al., 2018). It has been on the rise in recent years in Côte d'Ivoire, mainly in the South-East, Centre-West and West zones with estimated losses of 35 to $50 \%$ (Coulibaly, 2014; Coulibaly et al., 2018).

Faced with the threat of black pod disease, synthetic fungicides are essentially used (Mpika et al., 2009; Pohe et al., 2013; Bailey et al., 2016). Under optimal conditions, their effectiveness is certain. However, agrochemical use can be problematic due to risk of pesticides residues in cocoa beans, intoxication and environmental pollution (Deberdt et al., 2008; Yapo et al., 2014; Gramlich et al., 2016). In response to problems associated with pesticides use as well as consumer desire for organic chocolate (Gramlich et al., 2017; Kareem, 2016), a sustainable management method, less costly and environmentally friendly must be developed (Ten Hoopen and Krauss, 2016; Ouattara et al., 2020). Thus, there has been increased interest for biological control through the use of aromatic plants with antifungal and antibacterial properties (Oxenhan et al., 2005; Jiménez-Reyes et al., 2019). Extracts and essential oils of various aromatic plants have demonstrated their effectiveness for management of many plant diseases (Camara et al., 2007; Doumbouya et al., 2012; Pohe and Agneroh, 2013; Kassi et al., 2014). Several essential oils from plant species Azadirachta indica, Melaleuca alternifolia, Ocimum sp., exhibited antifungal activities against various pathogens commonly encountered on crop products (Camara et al., 2010; Doumbouya et al., 2012; Muthukumar et al., 2016; Tiendrebeogo et al., 2017). This study aimed at comparing the efficacy of essential oils of Cymbopogon citratus, Eucalyptus citriodora and Ocimum gratissimum species in vitro and in vivo against two Phytophthora strains (P. palmivora and $P$. megakarya) in a view to developing new biofongicides for the control of cocoa tree black pod disease.

\section{MATERIALS AND METHODS \\ Materials \\ Plant material}

Plant material consisted of cocoa trees leaves and those of aromatic plants. Cocoa leaves came from three clones, which susceptibility to black pod disease is known. These clones were NA32, PA150 and SCA6 respectively susceptible, moderately resistant and resistant to black pod disease. The clones were collected in plots of the reciprocal recurrent selection program's collection at National Agronomic Center Research (CNRA), Research station of Divo (Côte d'Ivoire). Aromatic plant leaves came from three species (Cymbopogon citratus, Eucalyptus citriodora and Ocimum gratissimum) known for their antimicrobial activities and collected in three regions: Abidjan (South-East), Divo (Centre-West) and Korhogo (North) of Côte d'Ivoire.

\section{Fungal material}

Fungal material consisted of two strains of Phytophthora: Phytophthora palmivora (Strain BL7.11.2) and P. megakarya (Strain 13P30.1). These strains were isolated from naturally affected cocoa pods by black pod disease (Mpika et al., 2009; Ouattara et al., 2020).

\section{Methods \\ Isolation and culture of Phytophthora}

Isolation of Phytophthora was performed by taking a piece of cocoa pod from the growth front of the pathogen (Mpika et al., 2009). This piece was placed on a $1.5 \%$ agar water medium. On this medium, the mycelium grew in the absence of bacteria. A mycelial fragment was taken from the growth front and transferred to a pea extract agar medium (Huguenin and Boccas, 1971). Incubation was carried out at $26{ }^{\circ} \mathrm{C}$ for 4 to 5 days. To avoid 
heterogeneity of zoospores, cloning of each strain by monozoospore isolation was carried out at according to the method described by Babacauh (1980).

\section{Extraction of essential oils}

The harvested leaves were previously dried at laboratory room temperature $\left(25^{\circ} \mathrm{C}\right)$ for 5 days followed by extraction of essential oils. These oils were obtained by steam entrainment performed with a Clevenger-type device for 3 hours (Oussou, 2009; Castro et al., 2010; Santos et al., 2013). This method is a classical distillation during which the plant material was immersed in water and the whole brought to boiling. The water vapor loaded with volatile substances condenses inside a refrigerant. The essences, which are less dense than water, were collected in flasks by simple decantation on the surface of the water. The flasks containing essentials oils were covered with aluminum foil to preserve them from any negative effect of light. The essentials oils were then stored in a refrigerator at a temperature of $12{ }^{\circ} \mathrm{C}$ (Oussou, 2009).

\section{In vitro activity of essential oils}

The antifungal activity of essential oils was evaluated in vitro and aimed to determine the minimum inhibitory concentration of these oils. The essential oils were aseptically incorporated at decreasing concentrations ( 0.5 ; $1 ; 3 ; 5 \mathrm{~mL} / \mathrm{L}$ ) into pea extract agar medium after autoclaving at $121{ }^{\circ} \mathrm{C}, 1$ bar for $30 \mathrm{~min}$ (Camara et al., 2010; Degnon et al., 2013; Kouamé et al., 2015 ). These media were poured at a rate of $20 \mathrm{~mL}$ into $9 \mathrm{~mm}$ diameter Petri dishes. For each concentration of each essential oil and for each strain of Phytophthora, four Petri dishes were inoculated with a mycelial explant of $6 \mathrm{~mm}$ diameter. These explants were die-cut from the growth front of a 4-day-old non-sporulating cultures. This explant was then placed into the center of each Petri dish. Controls without essential oils were prepared under the same conditions. Incubation was carried out at $26^{\circ} \mathrm{C}$. A measurement of each mycelial explant's growth diameter was done every 24 hours for 21 days. The means of 2 perpendicular diameters passing through the explants middle were calculated. These means were compared to controls. Daily measurements were used to assess essential oils antifungal action on the mycelial growth of both Phytophthora strains $(P$. palmivora and $P$. megakarya). The inhibition rates of mycelial growth exerted by the essential oils were calculated according to the following formula (Whipps, 1997):

$$
\text { I. }(\%)=(1-\mathrm{Dn} / \mathrm{Do}) \times 100
$$

Where I. (\%) is the mean inhibition rate; Dn is the mean diameter of mycelial growth in the presence of essential oils and Do is the mean diameter of mycelial growth without essential oil (control).

\section{In vivo activity of essential oils}

\section{Phytophthora strains inoculum preparation}

The inoculum of Phytophthora strains was a zoospores suspension. This suspension was obtained from a 5 or 6-day-old culture carried out in Roux flasks. Incubation was carried out under a 12-hour photoperiod for 10 days. The cultures were flooded with $40 \mathrm{~mL}$ of distilled water and placed for $15 \mathrm{~min}$ at $4{ }^{\circ} \mathrm{C}$. The cultures were then exposed for $45 \mathrm{~min}$ at room temperature to light from an incandescent lamp $(60 \mathrm{~W})$ in order to induce and accelerate sporogenesis (Babacauh, 1980). This heat shock operation allows the mature sporocysts to initiate the release of their zoospores. The zoospores suspensions obtained in each Roux flask were counted using a Malassez hemacytometer (SOVIREL, France) and calibrated to a concentration of $3 \times 10^{5}$ zoospores $/ \mathrm{mL}$ for leaf discs inoculation (Mpika et al., 2009).

\section{Cocoa leaf discs test}

The leaf discs test was used to assess the effect of essential oils on Phytophthora strains as described by Nyassé et al. (1995). Healthy young leaves of clones (NA32, PA150 and SCA6) were collected from non-lignified twigs. These leaves were then preconditioned to make lamina more receptive to inoculation. The leaves were placed overnight underside down, against a foam soaked in distilled water, in a hermetically sealed tray. Leaf discs of 15 $\mathrm{mm}$ diameter were prepared and arranged in a four factors split-plot completely randomized design with four (04) repetitions for each treatment. Thus, four lines of ten (10) leaf discs or forty (40) leaf discs per clone, per essential 
oil, per Phytophthora strain and per tray were inoculated (i.e.) 120 leaf discs for the three cocoa clones. For each treatment, leaf discs received $10 \mu \mathrm{L}$ of each concentration of essential oils suspensions and $10 \mu \mathrm{L}$ of Phytophthora zoospores suspensions. The controls received $20 \mu \mathrm{L}$ of sterile distilled water. After inoculation, the trays were sealed with black plastic film and incubated at $26^{\circ} \mathrm{C}$ in darkness for 7 days. Reduction rates (\%) of leaf susceptibility were calculated using the following formula (Gadji et al., 2018):

R. $(\%)=\frac{(A-B)}{A} \times 100$

Where: R. (\%) is the reduction rate of foliar susceptibility; A is the mean susceptibility indices of the control without essential oil; B is the mean foliar susceptibility indices of each treatment with the essential oils.

\section{Statistical analysis}

The data obtained were analyzed with SAS version 9.4 software. The mean leaf susceptibility indices were compared using an analysis of variance. The Student NewmanKeuls test was used to make multiple comparisons at the 0.05 probability threshold.

\section{RESULTS \\ In vitro effect of essential oils on the mycelial growth of two Phytophthora strains}

Tables 1, 2 and 3 show the results of mycelial growth of both Phytophthora strains after addition of the essential oils to the culture media. From the analysis of these results, it appears that after 21 days of incubation, the essential oils showed antimicrobial activity against both Phytophthora strains. This activity varied according to Phytophthora strains, essential oils and concentrations. Indeed, the three essential oils exerted an important inhibitory activity towards $P$. megakarya. A total inhibition rate (100\% inhibition) of mycelial growth was observed whatever the concentration $(0.5$ to $5 \mathrm{~mL} / \mathrm{L})$. However, with $P$. palmivora strain, a differential activity was observed. Inhibition rates of $17.70 \%$ and $52.20 \%$ were observed with the essential oil of Eucalyptus citriodora species applied at concentrations of 0.5 and $1 \mathrm{~mL} / \mathrm{L}$. A total inhibition rate $(100 \%)$ was noted with the concentration of $3 \mathrm{~mL} / \mathrm{L}$. Yet, with the essential oils of the species (Cymbopogon citratus and Ocimum gratissimum), high susceptibility of $P$. palmivora was observed at the minimum concentration of $0.5 \mathrm{~mL} / \mathrm{L}$ and the inhibition rates ranged from 83.80 to $85.27 \%$.

\section{In vivo effect of essential oils on cocoa clones susceptibility to Phytophthora strains}

Tables 4, 5 and 6 show the results of leaf discs treatments with essential oils of the three aromatic plant species against Phytophthora strains. These results showed a significant difference $(\mathrm{p}<0.05)$ between leaf susceptibility indices induced by essential oils to the clones (NA32, PA150 and SCA6) and which of the controls. Indeed, essential oils induced a reduction of leaf susceptibility to $P$. palmivora. The mean susceptibility indices varied from 0.40 to 1.05 (no necrosis spots) compared to the index of 3.00 (presence of necrosis spots) of the control. Similarly, a reduction of leaf susceptibility to P. megakrya was observed. With $P$. megakrya strain, the mean susceptibility indices ranged from 0.42 to 1.11 compared to the index of 3.16 for control. These indices reflect reduction rates of foliar susceptibility to Phytophthora ranging from 64.87 to $86.70 \%$ with the three essential oils applied at doses of 0.5 to $5 \mathrm{~mL} / \mathrm{L}$ (Table 7). However, these essential oils exerted more or less pronounced antifungal activity when applied at doses below $5 \mathrm{~mL} / \mathrm{L}$. Indeed, the essential oils (HO and HS) of Ocimum gratissimum and Cymbopogon citratus species exerted more pronounced antifungal activity than Eucalyptus citriodora species when applied at doses below $5 \mathrm{~mL} / \mathrm{L}$ (Table 7). 
Table 1: Inhibition rates of Phytophthora strains in the presence of essential oil from Eucalyptus citriodora species.

\begin{tabular}{|c|c|c|}
\hline \multirow{2}{*}{$\begin{array}{l}\text { Essential oil concentrations } \\
(\mathrm{mL} / \mathrm{L})\end{array}$} & \multicolumn{2}{|c|}{ Inhibition rate (\%) of Phytophthora strains mycelial growth } \\
\hline & Phytophthora palmivora & Phytophthora megakarya \\
\hline 0,5 & 17,7 & 100 \\
\hline 1 & 52,2 & 100 \\
\hline 3 & 100 & 100 \\
\hline 5 & 100 & 100 \\
\hline
\end{tabular}

Table 2: Inhibition rates of Phytophthora strains in the presence of essential oil from Cymbopogon citratus species.

\begin{tabular}{lcc}
$\begin{array}{l}\text { Essential oil concentrations } \\
(\mathrm{mL} / \mathrm{L})\end{array}$ & \multicolumn{2}{c}{ Inhibition rate (\%) of Phytophthora strains mycelial growth } \\
\cline { 2 - 3 } & Phytophthora palmivora & Phytophthora megakarya \\
\hline 0,5 & 83,80 & 100 \\
\hline 1 & 100 & 100 \\
\hline 3 & 100 & 100 \\
\hline 5 & 100 & 100 \\
\hline
\end{tabular}

Table 3: Inhibition rates of Phytophthora strains in the presence of essential oil from Ocimum gratissimum species.

\begin{tabular}{|c|c|c|}
\hline \multirow{2}{*}{$\begin{array}{l}\text { Essential oil concentrations } \\
(\mathrm{mL} / \mathrm{L})\end{array}$} & \multicolumn{2}{|c|}{ Inhibition rate (\%) of Phytophthora strains mycelial growth } \\
\hline & Phytophthora palmivora & Phytophthora megakarya \\
\hline 0,5 & 85,27 & 100 \\
\hline 1 & 100 & 100 \\
\hline 3 & 100 & 100 \\
\hline 5 & 100 & 100 \\
\hline
\end{tabular}


Table 4: Leaf susceptibility indices of clone NA32 after application of essential oils.

\begin{tabular}{|c|c|c|c|c|c|c|c|c|}
\hline Clone & & & & NA32 & & & & \\
\hline Phytophthora strains & & bytophth & ra palm & ora & & ytophth & ra mega & irya \\
\hline $\begin{array}{l}\text { Essential oil } \\
\text { concentrations }(\mathrm{mL} / \mathrm{L})\end{array}$ & HE & HO & HS & Control & HE & HO & HS & Control \\
\hline 0,5 & $2,03^{\mathrm{b}}$ & $1,03^{\mathrm{de}}$ & $0,60^{\mathrm{ef}}$ & $3,00^{\mathrm{a}}$ & $2,51^{\mathrm{b}}$ & $1,27^{\mathrm{c}}$ & $0,95^{\mathrm{cd}}$ & $3,16^{\mathrm{a}}$ \\
\hline 1 & $1,50^{\mathrm{c}}$ & $0,85^{\text {def }}$ & $0.70^{\text {def }}$ & $3,00^{\mathrm{a}}$ & $2,23^{\mathrm{b}}$ & $1,18^{\mathrm{c}}$ & $0,87^{\mathrm{cd}}$ & $3,16^{\mathrm{a}}$ \\
\hline 3 & $1,13^{\mathrm{d}}$ & $0,62^{\mathrm{ef}}$ & $0,47^{\mathrm{f}}$ & $3,00^{\mathrm{a}}$ & $1,28^{\mathrm{c}}$ & $0,91^{\mathrm{cd}}$ & $0,48^{\mathrm{d}}$ & $3,16^{\mathrm{a}}$ \\
\hline 5 & $1,05^{\mathrm{de}}$ & $0,40^{\mathrm{f}}$ & $0,48^{\mathrm{f}}$ & $3,00^{\mathrm{a}}$ & $1,11^{\mathrm{c}}$ & $0,83^{\mathrm{cd}}$ & $0,42^{\mathrm{d}}$ & $3,16^{\mathrm{a}}$ \\
\hline
\end{tabular}

Values with the same letter in the same column are not statistically different according to the Newman -Keuls test at the 5\% probability level $\mathrm{HE}=$ Ecalyptus citriodora essential oil; $\mathrm{HO}=$ Ocimum gratissimum essential oil; $\mathrm{HS}=$ Cymbopogon citratus essential oil; Control $=$ treatment without oil.

Table 5: Leaf susceptibility indices of clone PA150 after application of essential oils.

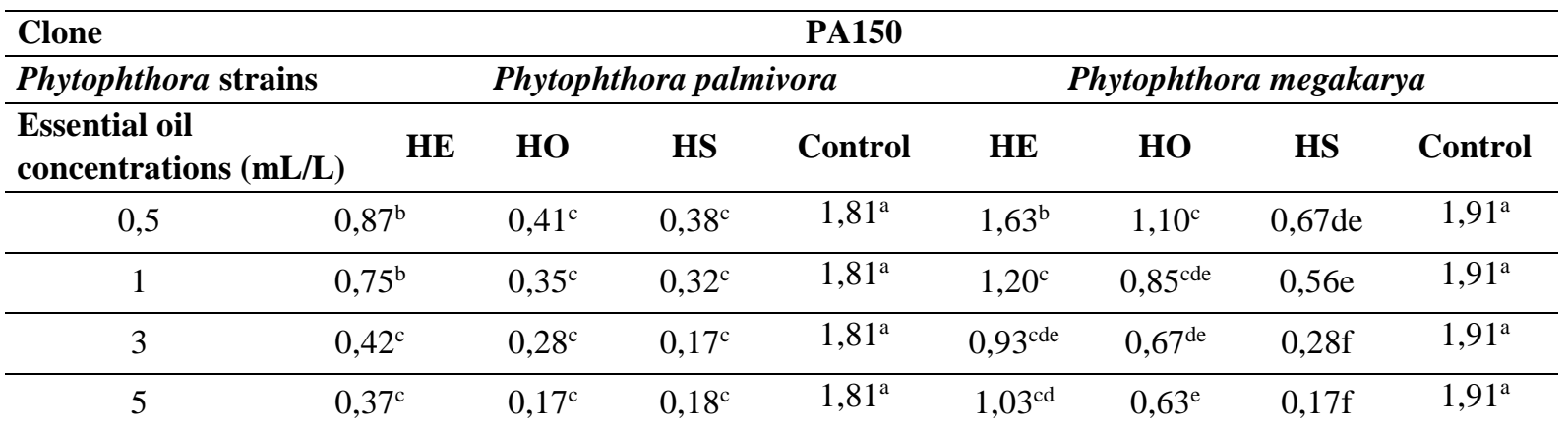

Values with the same letter in the same column are not statistically different according to the Newman -Keuls test at the 5\% probability level. $\mathrm{HE}=$ Ecalyptus citriodora essential oil; $\mathrm{HO}=$ Ocimum gratissimum essential oil; $\mathrm{HS}=$ Cymbopogon citratus essential oil; Control $=$ treatment without oil.

Table 6: Leaf susceptibility indices of clone SCA6 after application of essential oils.

\begin{tabular}{|c|c|c|c|c|c|c|c|c|}
\hline Clone & & & & SCA6 & & & & \\
\hline Phytophthora strains & & hytopht & palmi & & & ytophthe & a megak & arya \\
\hline $\begin{array}{l}\text { Essential oil } \\
\text { concentrations }(\mathrm{mL} / \mathrm{L})\end{array}$ & HE & HO & HS & Control & HE & HO & HS & Control \\
\hline 0,5 & $1,10^{\mathrm{b}}$ & $0,48^{\mathrm{cd}}$ & $0,28^{\mathrm{e}}$ & $1,57^{\mathrm{a}}$ & $1,85^{\mathrm{a}}$ & $1,17^{\mathrm{b}}$ & $0,65^{\text {cde }}$ & $1,68^{\mathrm{a}}$ \\
\hline 1 & $0,67^{\mathrm{c}}$ & $0,33^{\mathrm{de}}$ & $0,20^{\mathrm{e}}$ & $1,57^{\mathrm{a}}$ & $1,27^{\mathrm{b}}$ & $0,80^{\text {cd }}$ & $0,51^{\text {def }}$ & $1,68^{\mathrm{a}}$ \\
\hline 3 & $0,55^{\mathrm{c}}$ & $0,13^{\mathrm{e}}$ & $0,16^{\mathrm{e}}$ & $1,57^{\mathrm{a}}$ & $1,00^{\mathrm{bc}}$ & $0,72^{\text {cde }}$ & $0,31^{\mathrm{ef}}$ & $1,68^{\mathrm{a}}$ \\
\hline 5 & $0,25^{\mathrm{e}}$ & $0,16^{\mathrm{e}}$ & $0,11^{\mathrm{e}}$ & $1,57^{\mathrm{a}}$ & $0,60^{\text {cde }}$ & $0,45^{\text {def }}$ & $0,15^{\mathrm{f}}$ & $1,68^{\mathrm{a}}$ \\
\hline
\end{tabular}

Values with the same letter in the same column are not statistically different according to the Newman -Keuls test at the 5\% probability level. $\mathrm{HE}=$ Ecalyptus citriodora essential oil; $\mathrm{HO}=$ Ocimum gratissimum essential oil; $\mathrm{HS}=$ Cymbopogon citratus essential oil; Control $=$ treatment without oil. 
Table 7: Reduction rates of leaf susceptibility of clone NA32 induced by essential oils.

\begin{tabular}{lcccc}
\hline \multirow{2}{*}{ Essential oils } & \multicolumn{2}{l}{ Phytophthora palmivora } & \multicolumn{2}{l}{ Phytophthora megakarya } \\
\cline { 2 - 5 } & $\begin{array}{l}\text { Sensitivity } \\
\text { rating }\end{array}$ & Reduction rate (\%) & $\begin{array}{l}\text { Sensitivity } \\
\text { rating }\end{array}$ & $\begin{array}{c}\text { Reduction } \\
\text { rate }(\%)\end{array}$ \\
\hline $\begin{array}{l}\text { Phytophthora (Controls } \\
\text { without oils) }\end{array}$ & 3,00 & - & 3,16 & - \\
\hline Eucalyptus citriodora & 1,05 & $65 \mathrm{a}$ & 1,11 & $64,87 \mathrm{a}$ \\
\hline Ocimum gratissimum & 0,40 & $86,66 \mathrm{~b}$ & 0,83 & $73,73 \mathrm{~b}$ \\
\hline Cymbopogon citratus & 0,48 & $84 \mathrm{~b}$ & 0,42 & $86,70 \mathrm{c}$ \\
\hline
\end{tabular}

Values with the same letter in the same column are not statistically different according to the Newman -Keuls test at the 5\% probability level.

\section{DISCUSSION}

Essential oils significantly reduced mycelial growth in vitro and leaf susceptibility to both Phytophthora strains. This revealed the toxicity of essential oils towards Phytophthora strains. Indeed, the antifungal and insecticidal properties of essential oils from aromatics plant species (Ocimum gratissimum, Eucalyptus citriodora and Cymbopogon citratus) were reported by several research works (Camara et al., 2007; Camara, 2009; Camara et al., 2010; Degnon et al., 2013; Kassi et al., 2014; Muthukumar et al., 2016; Ouedraogo et al., 2016; Tia et al., 2019). Most essential oils have a broad spectrum of action against fungi, bacteria, insects, nematodes and viruses (Camara et al., 2010). Their activity could depend on the nature and chemical structure of their constituents (Camara et al., 2007). Thus, the presence of hydroxyl group in phenolic compounds would confer an antioxidant property to aromatic plants (Shahidi et al., 1992). Other studies have confirmed the inhibitory action of monoterpenes on the growth of microorganisms including Phytophthora (Camara et al., 2010; Soro et al., 2020). Monoterpenes would act by increasing microorganisms' cellular permeability (Arras and Usai, 2001) and by degrading their nucleic acids (Lambert et al., 2001). Antimicrobial activity of the essential oil from Eucalyptus citriodora species is due to various molecules such as 1,8-cineole, citronellal, citronellol, citronellyl acetate, p-cymene, eucamalol, limonene, linalool, $\alpha$-pinene, $\gamma$-terpinene, $\alpha$ terpineol, alloocimene, and aromadendrene ( $\mathrm{Su}$ et al., 2006; Batish et al., 2008; Liu et al., 2008; Traore et al., 2013). According to Camara et al. (2007), the different activities (fungistatic and fungitoxic) of the essential oil from Ocimum gratissimum species are mainly due to a chemical constituent present at $93.9 \%$ (eugenol). Eugenol is known to have antimicrobial activity (Camara et al., 2007). According to Kobenan et al. (2019), the chemical analysis of Cymbopogon citratus species essential oil showed a high proportion of oxygenated monoterpenes $(73.1 \%)$ with a predominance of $\alpha$-citral $(31.89 \%)$ and neral (39.33\%).

Phytophthora megakarya strain was more sensitive in vitro to the effect of essential oils than $P$. palmivora strain. Indeed, the minimum concentration of total inhibition $\left(\mathrm{CI}_{100}\right)$ of mycelial growth of $P$. palmivora strain was $1 \mathrm{~mL} / \mathrm{L}$ for both essential oils from Ocimum gratissimum and Cymbopogon citratus species against a concentration of 3 $\mathrm{mL} / \mathrm{L}$ for Eucalyptus citriodora species essential oil. However, the minimum concentration of these three essential oils that completely inhibited mycelial growth of the $P$. megakarya strain was $0.5 \mathrm{~mL} / \mathrm{L}$. This difference in susceptibility of the two 
Phytophthora strains could be explained by the fact that the Phytophthora megakarya strain is slower growing in vitro compared to the Phytophthora palmivora strain (Mpika et al., 2009; Coulibaly et al., 2018; Ouattara et al., 2020). Thus, with the Phytophthora megakarya strain, the oils have time to act on the mycelial walls before the expiration of the strain's latency time, which varies from 48 to 72 hours at $26{ }^{\circ} \mathrm{C}$ in darkness. This is not the case for Phytophthora palmivora strain which has rather a short latency time ( 24 to 48 hours $26{ }^{\circ} \mathrm{C}$ in darkness); (Mpika et al., 2009; Coulibaly et al., 2018; Ouattara et al., 2020). Similar results were obtained by Soro et al. (2020), who observed in vitro a total inhibition of Phytophthora palmivora strain with a concentration $\left(\mathrm{CI}_{100}\right)$ of $200 \mathrm{ppm}$ with Ocimum gratissimum species essential oil. Doumbouya et al. (2012) observed 90\% inhibition of mycelial growth of Pythium sp. with Ocimum gratissimum species essential oil at a concentration of $100 \mathrm{ppm}\left(\mathrm{CI}_{90}\right)$.

\section{Conclusion}

Essential oils from aromatic plant species (Ocimum gratissimum, Eucalyptus citriodora and Cymbopogon citratus) revealed reducing properties on mycelial growth of $P$. palmivora and $P$. megakarya strains. In addition, these oils also reduced in vivo the foliar susceptibility of clones (NA32, PA150 and SCA6) to both Phytophthora strains. Essential oils from Cymbopogon citratus and Ocimum gratissimum species were most effective than which from Eucalyptus citriodora species. The minimal dose of 0,5 $\mathrm{mL} / \mathrm{mL}$ of essential oils from Cymbopogon citratus and Ocimum gratissimum species and the dose of $3 \mathrm{~mL} / \mathrm{mL}$ for which of Eucalyptus citriodora species could be used for the control of black pod disease in field condition. These essential oils therefore revealed biofungicidal properties against Phytophthora and could be recommended as an alternative in the biological control of black pod disease in Côte d'Ivoire.

\section{COMPETING INTERESTS}

The authors declare that they have no competing interests.

\section{AUTHORS' CONTRIBUTIONS}

$\mathrm{KC}$ and FJMKK designed the protocol; $\mathrm{AO}$ and other authors participated in the study and contributed to the writing of the manuscript. DK and FKN supervised the study. All the authors read and approved the final version of the manuscript.

\section{ACKNOWLEDGEMENTS}

We sincerely thank the Laboratory of Plant Physiology at Félix Houphouët-Boigny University for providing us with the essential oils. We also thank Misters Coulibaly Bakary, Research technician, and Touré Laurent, Research assistant at the Laboratory of Plant pathology, National Center of Agronomic Research (CNRA), Research Station of Divo (Côte d'Ivoire), for the appreciable help provided during the leaf inoculation tests.

\section{REFERENCES}

Arras G, Usai M. 2001. Fungitoxic activity of 12 oils against four postharvest citrus pathogens: chemical analysis of Thymus capitatus oil and its effect in subatmospheric pressure conditions. $J$. Food Prot., 64(7): 1025-1029. DOI: https://doi.org/10.4315/0362-028X64.7.1025

Assiri AA, Kacou EA, Assi FA, Ekra S, Dji KF, Couloud JY, Yapo AR. 2012. Rentabilité économique des techniques de réhabilitation et de replantation des vieux vergers de cacaoyers (Theobroma cacao L.) en Côte d'Ivoire. Journal of Animal and Plant Sciences, 14(2): 939-1951. https://www.m.elewa.org/JAPS/2012/14. 2/3.pdf

Babacauh KD. 1980. Structure et dynamique des populations de Phytophthora sp. Parasite du cacaoyer (Theobroma cacao L.). Thèse de Doctorat d'Etat, Université de Paris-Sud, centre d'Orsay, France, 153 p.

Bailey BA, Ali SS, Meinhardt LW. 2016. Phytophthora megakarya, a Causal Agent 
of Black Pod Rot in Africa. In: Cacao Diseases: A History of Old Enemies and New Encounters, Bryan AB, Meinhardt LW (Eds). Springer International Publishing: Switzerland; 267-306. DOI:10.1007/978-3-319-24789-2

Batish DR, Singh HP, Kohli RK, Kaur S. 2008. Eucalyptus essential oil as a natural pesticide. Forest Ecology and Management, 256(12): 2166-2174. DOI: 10.1016/j.foreco.2008.08.008

Camara A. 2009. Lutte Contre Sitophilus Oryzae L. (Coleoptera: Curculionidae) Et Tribolium Castaneumherbst (Coleoptera: Tenebrionidae) dans les stocks de riz par la technique d'étuvage traditionnelle pratiquée en Basse-Guinée et l'utilisation des huiles essentielles végétales. Thèse de Doctorat, en Sciences de l'Environnement, Université du Québec, Montréal, Canada, 173p.

Camara B, Dick E, Sako A, Kone D, Kanko C, Boye M.-A.-D, Ake S, Anno A. 2010. Lutte biologique contre Deightoniella torulosa (Syd.) Ellis, par l'application des huiles essentielles d'Eucalyptus platyphylla F. Muell. et de Melaleuca quinquenervia L. Phytothérapie et Ecologie, 8: 240-244. DOI: 10.1007/s10298-010-0568-3

Camara B, Koné D, Kanko C, Anno A, Aké S. 2007. Activité antifongique des huiles essentielles de Ocimum gratissimum L., de Monodora myristica (Gaaertn) Dunal et de deux produits de synthèses (Impulse et Folicur), sur la croissance mycélienne et la production de spore in vitro de Deightoniella torulosa (Syd.) Ellis. Revue Ivoirienne de Science et Technologie, 09: 190-198.

Castro HG, Perini VBM, Santos GR, Lea TCAB. 2010. Evaluation of content and composition of the essential oil of Cymbopogon nardus (L.) in different harvest times. Revista Ciência Agronômica. 41(2): 308-314. DOI: https://doi.org/10.1590/S180666902010000200020

CCC (Conseil Café-Cacao). 2014. Rapport de la session. Plateforme de partenariat public-privé de la filière café-cacao, troisième session plénière / Hôtel Du Golf, Abidjan. Côte d'Ivoire, 14p.

Coulibaly K. 2014. Étude de la structure des populations de Phytophthora spp, agent de la pourriture brune des cabosses de cacaoyers (Theobroma cacao L.) en Côte d'Ivoire. Thèse de Doctorat en Pathologie et Physiologie Végétales. Université Félix Houphouët-Boigny. Abidjan, Côte d'Ivoire, 190p.

Coulibaly K, Aka RA, Camara B, Kassin E, Kouakou K, Kébé BI, Koffi NK, Tahi MG, Walet NP, Guiraud SB, Assi ME, Kone B, N'Guessan KF, Koné D. 2018. Molecular Identification of Phytophthora palmivora in the Cocoa Tree Orchard of Côte d'Ivoire and Assessment of the Quantitative Component of Pathogenicity. International Journal of Sciences, 7(8): 7-15. DOI: 10.18483/ijSci.1707

Deberdt P, Mfegue CV, Tondje PR, Bon MC, Ducamp M, Hurard C, Begoude BAD, Ndoumbe-Nkeng M, Hebbar PK, Cilas C. 2008. Impact of environmental factors, chemical fungicide and biological control on cacao pod production dynamics and black pod disease (Phytophthora megakarya) in Cameroon. Biological Control, 44: 149-159. DOI: https://doi.org/10.1016/j.biocontrol.2007 .10 .026

Degnon RG; Faton A-N, Adjou ES, Tchobo FP, Dahouenon-Ahoussi E, Soumanou MM, Sohounhloue DCK. 2013. Efficacité comparée des huiles essentielles de deux plantes aromatiques dans la conservation post-fumage du Chinchard (Trachurus trachurus). Journal of Animal \& Plant Sciences, 19(1): 2831-2839.

Doumbouya M, Abo K, Lepengue AN, Camara B, Kanko K, Aïdara D, Kone D. 2012. Activités comparées in vitro de deux fongicides de synthèse et de deux huiles essentielles, sur des champignons telluriques des cultures maraîchères en Côte d'Ivoire. Journal of Applied Biosciences, $\quad$ 50: 3520-3532. http://m.elewa.org/JABS/2012/50/8.pdf 
Friedel H.-A, Claudia H, Irene K, Pedro M, Mara M. 2016. Renforcer la compétitivité de la production de cacao et augmenter le revenu des producteurs de cacao en Afrique de l'Ouest et en Afrique central, 84p.

Gadji AAG, Kouamé KG, Coulibaly K, Yapo OB, Aka AR, Brar KS, Tyagi R, Abo K. 2018. Effect of Bacillus thuringiensis var. kurstaki HD-1-based biopesticide on the pathogenicity of Phytophthora palmivora. Journal of Biodiversity and Environmental Sciences, 12(5): 456-464.

Gramlich A, Tandya S, Andres C, Chincheros PJ, Armengot L, Schneider M, Schulin R. 2017. Cadmium uptake by cocoa trees in agroforestry and monoculture systems under conventional and organic management. Science of the Total Environment, 580: 677-686. DOI: http://dx.doi.org/10.1016/j.scitotenv.201 6.12 .014

Huguenin G, Boccas B. 1971. Rôle de quelques facteurs dans la formation et la germination des zoospores chez le Phytophthora palmivora Bult. Ann. Phytopathol., 3(3) : 353-71.

ICCO (International Cocoa \& Chocolate Organisation). 2000. Célébration du cacao, $115 \mathrm{p}$.

ICCO. 2019. Quarterly Bulletin of Cocoa Statistics, Vol. XLV, No.3, Cocoa year 2018/19. 1p.

Jiménez-Reyesa MF, Carrascob H, Oleab AF, Silva-Moreno E. 2019. Natural compounds: a sustainable alternative to the phytopathogens control. J. Chil. Chem. Soc., 64(2): 4459- 4465. DOI: http://dx.doi.org/10.4067/S0711797072019000204459

Kareem OI. 2016. Cocoa exports'effects of the European Union's SPS measures. International Journal of Sustainable Economy, 8(1): 76-89. DOI: 10.1504/IJSE.2016.073686

Kassi MF, Badou JO, Tonzibo FZ, Salah Z, Bolou ABB, Camara B, Amari EGDN-L, Koné D. 2014. Potentiel antifongique de l'huile essentielle de Ocimum gratissimum dans la lutte biologique contre la maladie des raies noires du bananier causée par Mycosphaerella fijiensis Morelet (Mycosphaerellacea). Agronomie Africaine, 26(2) : 1-11. DOI: https://www.ajol.info/index.php/aga/artic le/view/107197/97087

Kobenan KC, Kouakou BJ, Bini KKN, Kouakou M, Dick AE, Ochou OG. 2019. Effets des Huiles Essentielles de Ocimum gratissimum L. et de Cymbopogon citratus Stapf sur les Paramètres de Croissance et de Production du Cotonnier en Côte d'Ivoire. European Journal of Scientific Research, 154(1): 21-35.

Kouamé KG, Kouassi KN, Kassi FM, Bolou BBA, Tuo S, Kanko C, Kone D. 2015. Antifungal Activity of Essential Oils Extracted from Monodora myristica (Gaertn), Ocimum gratissimum L. and Zingiber officinalis Roscoe on Postharvest Anthracnose of Mango Fruit (Mangifera indica L.) Variety Kent in Côte d'Ivoire. International Journal of Sciences, 4(12): $\quad 8-18 . \quad$ DOI: 10.18483/ijSci.869

Lambert RJW, Sjandamis PN, Coote PJ, Nychas GJE. 2001. A study of the minimum inhibitory concentration and mode of action of oregano essential oil, thymol and carvacrol. J. Appl. Microbiol., 91: 453-62. DOI: $10.1046 / j .1365-$ 2672.2001.01428.x

Liu X, Chen Q, Wang Z, Xie L, Xu Z. 2008. Allelopathic effects of essential oil from Eucalyptus grandis E. urophylla on pathogenic fungi and pest insects. Front. Forestry China, 3: 232-236. DOI: https://doi.org/10.1007/s11461-0080036-5

Mpika J, Kébé IB, Issali AE, N'Guessan FK, Druzhinina S, Komon-Zélazowska M, Kubicek CP, Aké S. 2009. Antagonist potential of Trichoderma indigenous isolates for biological control of Phytophthora palmivora the causative agent of black pod disease on cocoa (Theobroma cacao L.) in Côte d'Ivoire. African Journal of Biotechnology, 8(20): 5280-5293.

DOI: 10.4314/ajb.v8i20.65962 
Muthukumar A, Sangeetha G, Naveenkumar R. 2016. Antimicrobial activity of essential oils against seed borne fungi of rice (Oryza sativa L.). Journal of Environmental Biology, 37: 1429-1436.

Nyassé S, Cilas C, Herail C, Blaha G. 1995. Leaf inoculation as an early screening test for cocoa (Theobroma cacao L.) resistance to Phytophthora black pod disease. Crop Protection, 14(8): 657-663. DOI: $\quad$ https://doi.org/10.1016/02612194(95)00054-2

Ouattara A, Coulibaly K, Konate I, Kebe B.I, Beugre GAM, Tidou AS, Abdelkarim F.M. 2020. Screening and Selection in vitro and in vivo of Cocoa Tree (Theobroma Cacao Linn) Endophytic Bacteria Having Antagonistic Effects against Phytophthora Spp. Fungal Agents Responsible of Black Pod Disease in Côte d'Ivoire. Journal of Applied \& Environmental Microbiology, 8(1): 2531. DOI:10.12691/jaem-8-1-4

Ouedraogo I, Sawadogo A, Nebie RC, Dakouo D. 2016. Evaluation de la toxicité des huiles essentielles de Cymbopogon nardus (L) et Ocimum gratissimum (L) contre Sitophilus zeamais Motsch et Rhyzopertha dominica $\mathrm{F}$, les principaux insectes nuisibles au maïs en stockage au Burkina Faso. Int. J. Biol. Chem. Sci., 10(2): 695-705. DOI: http://dx.doi.org/10.4314/ijbcs.v10i2.2

Oussou KR. 2009. Étude chimique et activités biologiques des huiles essentielles de sept plantes aromatiques de la pharmacopée ivoirienne. Thèse de Doctorat Unique. Laboratoire de chimie organique et biologique, UFR SSMT, Université de Cocody-Abidjan. 241p.

Oxenham SK, Svoboda KP, Walters DR. 2005. Antifungal activity of essential oil Basil (Ocimum basilicum). Phytopathology, 153: 174-180.

DOI: https://doi.org/10.1111/j.14390434.2005.00952.x

Ploetz R. 2016. The Impact of Diseases on Cacao Production: A Global Overview. In Cacao Diseases: A History of Old Enemies and New Encounters, Bailey
BA, Meinhardt LW (Eds). Springer International Publishing: Switzerland; Beltsville, USA: 33-59. DOI: 10.1007/978-3-319-24789-2

Pohe J, Agneroh TA. 2013. L'huile des graines de neem, un fongicide alternatif à l'oxyde de cuivre dans la lutte contre la pourriture brune des cabosses de cacaoyer en Côte d'Ivoire. Journal of Applied Biosciences, 62: 4644-4652. $\quad$ DOI: 10.4314/jab.v62i0.86147

Pohe J, Pohe SSW, Okou SFF. 2013. Association oxyde de cuivre et metalaxyl dans la lutte contre la pourriture brune des cabosses de cacaoyer en Côte d'Ivoire. Journal of Animal \& Plant Sciences, 16(3): 2362-2368. DOI: https://www.m.elewa.org/JAPS/2013/16. 3/2.pdf

Santos GR, Brum RBCS, Castro HG, Gonçalves CG, Fidelis RR. 2013. Effect of essential oils of medicinal plants on leaf blotch in Tanzania grass. Revista Ciência Agronômica, 44(3): 587-593. DOI: http://dx.doi.org/10.1590/S180666902013000300022

Shahidi F, Janitha PK, Wanasundara PD. 1992. Phenolic antioxidants. Crit. Rev. Food Sci. Nutr., 32: 67-103. DOI: https://doi.org/10.1080/10408399209527 581

Soro S, Ayolie K, Aye SEV, Fofana B, Silue N, Soro NA, Kone D. 2020. Six fungicidal formulations to control Phytophthora palmivora causal agent of brown rot of cocoa pods in Côte d'Ivoire. Journal of Global Biosciences, 9(10): 8088-8101.

https://www.mutagens.co.in/jgb/vol.09/1 0/091010.pdf

Su YC, Ho CL, Wang IC, Chang ST. 2006. Antifungal activities and chemical compositions of essential oils from leaves of four eucalypts. Taiwan J. For. Sci., 21: 49-61.

Ten Hoopen GM, Krauss U. 2016. Biological Control of Cacao Diseases In Cacao Diseases: A History of Old Enemies and New Encounters, Bailey BA, Meinhardt LW (Eds). Springer International 
Publishing: Switzerland; 511-566. DOI: 10.1007/978-3-319-24789-2

Tia EV, Cisse M, Douan GB, Kone A. 2019. Etude comparée de l'effet insecticide des huiles essentielles de Cymbopogon citratus DC et d'Ocimum canum Sims sur Cylas puncticollis Boheman, un charançon de la patate douce. Int. J. Biol. Chem. Sci., 13(3): 1789-1799. DOI: 10.4314/ijbcs.v13i3.46

Tiendrebeogo A, Ouedraogo I, Bonzi Skassankogno AI. 2017. Etude de l'activité antifongique d'extraits de Cymbopogon citratus (DC.) Stap, Eclipta alba L., Lippia multiflora M. et Agave sisalana P. Int. J. Biol. Chem. Sci., 11(3): 1202-1211.

DOI: https://dx.doi.org/10.4314/ijbcs.v11i3.22

Traore N, Sidibe L, Bouare S, Harama D, Somboro A, Fofana B, Diallo D,
Figueredo G, J-C. Chalchat. 2013. Activités antimicrobiennes des huiles essentielles de Eucalyptus citriodora Hook et Eucalyptus houseana W.Fitzg. ex Maiden. Int. J. Biol. Chem. Sci., 7(2): 800-804.

DOI: http://dx.doi.org/10.4314/ijbcs.v7i2.34

Whipps JK. 1997. Development in the biologicale control of soil-borne plant pathogens. Advances in Botanical Research, 26: 1-134. DOI: https://doi.org/10.1016/S00652296(08)60119-6

Yapo KD, Ouffoue SK, N'guessan BR, Okpekon TA, Dade J, Say M, Kouako TH. 2014. Quality control by the determination of heavy metals in new variety of cocoa (cocoa mercedes) Côte d'Ivoire. Journal de la Société OuestAfricaine de Chimie, 037: 56-64. 